\title{
Adenoma of the gallbladder in a mongoose (Mungos mungo)
}

\author{
Adenoma de vesícula biliar em mangusto (Mungos mungo)
}

\author{
Saulo Pereira Cardoso ${ }^{\mathrm{I}}$ Mariana Portugal Mattioli ${ }^{\mathrm{II}}$ Betânia Pereira Borges ${ }^{\text {III }}$ \\ Guilherme Reis Blume ${ }^{\mathrm{IV}}$ Janildo Ludolf Reis Júnior ${ }^{\mathrm{V}}$ Fabiano José Ferreira de Sant'Ana ${ }^{\mathrm{IV} *}$
}

\section{- NOTE -}

\section{ABSTRACT}

Primary gallbladder neoplasms occur infrequently in domestic animals and rarely in wild animals. This article describes a case of gallbladder adenoma in a mongoose (Mungos mungo) in captivity. Grossly, the gallbladder was moderately distended with a smooth capsular surface. Necropsy showed an irregular, soft, whitish nodule $0.8 \mathrm{~cm}$ in diameter. Microscopic examination of the nodule showed proliferation of epithelial cells, which projected from the mucosa and formed papillary projections supported by a sparse fibrovascular stroma. Neoplastic cells were well differentiated with mild anisocytosis and anisokaryosis. Based on these histopathological findings, adenoma of the gallbladder was diagnosed.

Key words: oncology, neoplasia, wild animals.

RESUMO

Neoplasmas primárias de vesícula biliar são incomumente descritas em animais domésticos e, raramente, afetam animais silvestres. Este trabalho tem por objetivo descrever um caso de adenoma de vesícula biliar em mangusto (Mungos mungo) mantido em cativeiro. Macroscopicamente, a vesícula biliar estava moderadamente distendida, com superficie lisa e, em seu interior, havia um nódulo esbranquiçado, irregular, macio, de $0,8 \mathrm{~cm}$ de diâmetro. Microscopicamente, havia proliferação neoplásica, epitelial, bem diferenciada, com projeções papilares da mucosa contendo células cilindricas. Observou-se anisocitose e anisocariose leve. Com base nos achados histopatológicos, foi firmado o diagnóstico de adenoma de vesícula biliar.

Palavras-chave: oncologia, neoplasia, animais silvestres.
Primary neoplasms of the gallbladder occur infrequently in domestic animals and rarely in wild animals. Epithelial neoplasms are common (PONOMARK \& MACKEY, 1976; JONES et al., 1997); whereas, mesenchymal neoplasms are extremely rare (SANT'ANA et al., 2000). Primary neoplasms of the gallbladder in domestic animals include adenomas (CULEN \& POPP, 2002), leiomyomas (SANT'ANA et al., 2000), carcinomas (CULEN \& POPP, 2002; SAKAI et al., 2003), and carcinoid tumors (MORREL et al., 2002). The only reports of gallbladder neoplasms in wild animals in the literature are as follows: an adenoma in a chimpanzee (STAROST \& MARTINO, 2002) and a bearded dragon (JAKAB et al., 2011), an adenocarcinoma in two African lions in captivity (SAKAI et al., 2003), and biliary tumors (two adenomas and five carcinomas) in prosimian primates in a retrospective study (REMICK et al., 2009).

Adenomas of the gallbladder distend the organ. They have a smooth surface and are difficult to recognize if the organ is intact (CULEN \& POPP, 2002). Microscopically, they have papillary extensions that project into the lumen of the gallbladder or can present as a cystic variant. Adenoma cells are cuboidal or columnar, line the epithelium of the tubules and papillae, and contain abundant apical mucin, which

\footnotetext{
Instituto Federal de Mato Grosso, Barra do Garças, MT, Brasil.

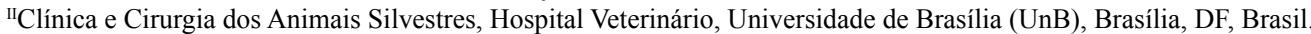

"IIFundação Jardim Zoológico de Brasília, Brasília, DF, Brasil.

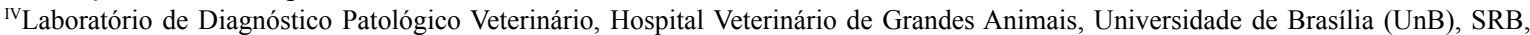
Área Especial, Granja do Torto, 70636-020, Brasília, DF, Brasil. E-mail: santanafjf@yahoo.com. "Corresponding author.

vDepartamento de Medicina Veterinária, Universidade Federal de Juiz de Fora (UFJF), Juiz de Fora, MG, Brasil.
} 
imparts a clear appearance to the cytoplasm in optic microscopy. Mitotic figures are rare, and there is no inflammatory infiltrate (CULEN \& POPP, 2002). This article describes the anatomopathological findings of an adenoma of the gallbladder in a mongoose (Mungos mungo).

A 8-year-old, $1.0 \mathrm{~kg}$ male mongoose at the "Fundação Jardim Zoológico de Brasília" in Brazil presented an exsudative, alopecic, cutaneous lesion in the base of the tail. The mongoose was anxious in its enclosure and often licked or bit the local of the lesion. It died 3 days after beginning treatment for the cutaneous lesion. For necropsy, samples of liver, gallbladder, lung, heart, kidney, intestine, and brain were collected and posteriorly fixed in $10 \%$ buffered formalin. Tissues were processed for routine histopathological evaluation and stained with hematoxylin and eosin.

Grossly, the liver had a diffuse, moderately pronounced lobular pattern. The gallbladder was moderately distended and had a smooth surface. A smooth, irregular, whitish nodule $0.8 \mathrm{~cm}$ in diameter occupied approximately $95 \%$ of the lumen of the gallbladder (Figure 1A). Microscopic examination of the nodule showed moderate proliferation of neoplastic epithelial cells, which were cylindrical with indistinct borders and projected from the mucosa into the lumen. These cells formed numerous tubule papillary projections (Figure 1B) that were sustained by a lamina propria composed of mild to moderate amounts of fibrovascular tissue (Figure 1C). Cytoplasm of the neoplastic cells was eosinophilic, clear, wide, and homogeneous. Nuclei were eccentric, basophilic, and round, with loose chromatin and one or two prominent nucleoli. There was mild anisocytosis and anisokaryosis. Nuclear/ cytoplasmic ratio was approximately $1: 3$, and rare mitotic figures were observed. The lumen of many of the tubules was filled with mucus. Multifocal areas with a mild infiltrate of lymphocytes, plasma cells,

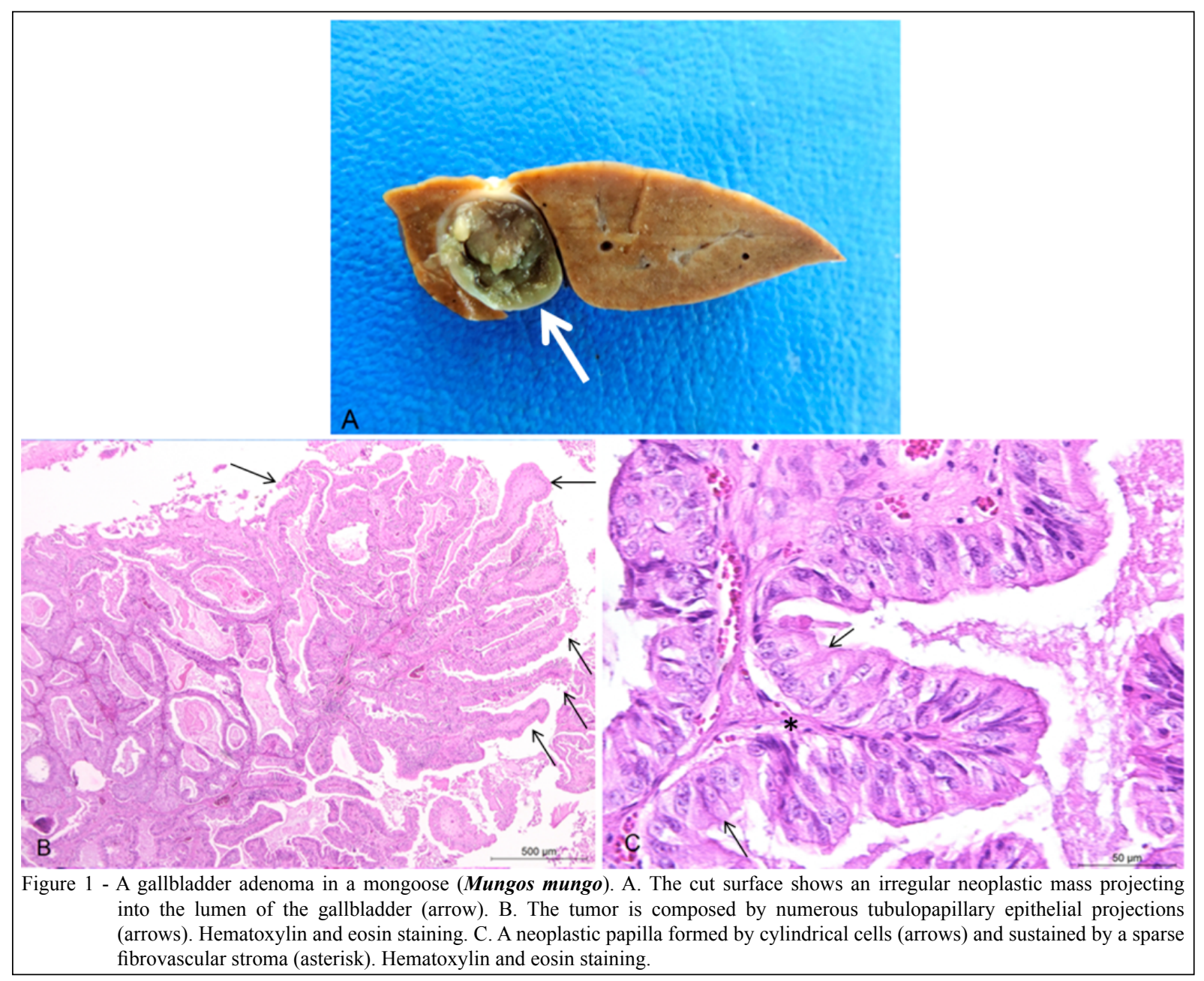

Ciência Rural, v.46, n.7, jul, 2016. 
and histiocytes were noted in the stroma. Based on these anatomopathological findings, papillar adenoma of the gallbladder was diagnosed.

According to its current description, adenoma of the gallbladder is considered an incidental finding; unlike other neoplasms in this organ, there are no clinical signs indicating possible impairment of bile elimination in the small intestine (SANT'ANA et al., 2000). Adenomas of the gallbladder are mostly observed in cattle and rarely in other domestic animals (CULEN \& POPP, 2002) or wild animals (STAROST \& MARTINO, 2002; JAKAB et al., 2011). Biliary tumors comprise $6 \%$ of all neoplasms in prosimian primates (REMICK et al., 2009). The cause of neoplasms of the gallbladder in domestic animals is unknown. Intrahepatic biliar epithelium is susceptible to some carcinogenic chemicals (e.g., $o$-aminoazotoluene, methylcholanthrene, and aramite in experimental models); however, whether these substances contribute to the genesis of neoplasms of the gallbladder in natural conditions is not known (ANDERSON et al., 1958). In the current case, there was no information about the exposure of the mongoose to these compounds.

Distention of the gallbladder wall in the absence of external irregularities can be detected via gross examination of the adenoma (CULEN \& POPP, 2002), as in the current case. Filling of the lumen of the tubulopapillary structures of gallbladder neoplasms indicates secretion by the neoplastic epithelial cells (STAROST \& MARTINO, 2002). Histopathological findings in the current study are very similar to those previously described for gallbladder adenomas in other species, such as chimpanzee (STAROST \& MARTINO, 2002) and bearded dragon (JAKAB et al., 2011). In some cases of papillary adenomas of the gallbladder, cystic projections, termed papillary cystoadenomas, can occur (CULEN \& POPP, 2002); these were not observed in the current case.

Neoplasms in the mongoose are rarely described, and our case contributes to the knowledge base of diseases in this species. Based on a review of the pertinent literature, these is the first report of adenoma of gallbladder in Mungos mungo.

\section{REFERENCES}

ANDERSON, W.A. et al. Epithelial tumors of the bovine gall bladder: a report of eighteen cases. American Journal of Veterinary Research, v.19, n.1, p.58-65, 1958.

CULEN, J.M.; POPP, J.A. Tumors of the liver and gall bladder. In: MEUTEN, D.J. Tumors in domestic animals. Iowa: Blackwel Publishing, 2002. Cap.9, p.499-501.

JAKAB, C. et al. Claudin-7-positive synchronous spontaneous intrahepatic cholangiocarcinoma, adenocarcinoma and adenomas of the gallbladder in a Bearded dragon (Pogona vitticeps). Acta Veterinaria Hungarica, v.59, n.1, p.99-112, 2011. Available from: $<$ http://www.akademiai.com/content/6616037340833608/?genr $\mathrm{e}=$ article \&id $=$ doi\%3a10.1556\%2fAVet.59.2011.1.9>. Accessed: Sept. 08, 2014. doi: 10.1556/AVet.59.2011.1.9.

MORREL, C.N. et al. A carcinoid tumor in the gallbladder of a dog. Veterinary Pathology, v.39, n.6, p.756-758, 2002. Available from: <http://vet.sagepub.com/cgi/pmidlookup?view=long\&pm $\mathrm{id}=12450211>$. Accessed: Dec. 03, 2014. doi: 10.1354/vp.39-6-756.

REMICK, A.K. et al. Neoplasia in prosimians: case series from a captive prosimian population and literature review. Veterinary Pathology, v.46, n.4, p.746-772, 2009. Available from: $<\mathrm{http} / /$ vet.sagepub.com/content/46/4/746.full.pdf + html $>$. Accessed: Oct. 07, 2015. doi: 10.1354/vp.08-VP-0154-R-FL.

SAKAI, H. et al. Gallbladder adenocarcinomas in two captive African lions (Panthera leo). Journal of Zoo and Wildlife Medicine, v.34, n.3, p.302-306, 2003. Available from: <http:// www.jstor.org/stable/20460337>. Accessed: Jan. 12, 2015. doi: 10.1638/1042-7260(2003)034[0302:GAITCA]2.0.CO;2.

SANT'ANA, F.J.F. et al. Leiomyoma of the gall bladder in a dog. Arquivo Brasileiro de Medicina Veterinária e Zootecnia, v.52, n.1, p.23-24, 2000. Available from: $<$ http://www.scielo.br/scielo.php?script=sci arttext\&pid $=$ S0102-09352000000100006 $>$. Accessed: Sept. 08, 2014. doi 10.1590/S0102-09352000000100006.

STAROST, M.F.; MARTINO, M. Adenoma of the gallbladder in a chimpanzee (Pan troglodytes). Journal of Zoo and Wildlife Medicine, v.33,n.2,p.176-177,2002. Available from:<http://www. bioone.org/doi/full/10.1638/1042-7260\%282002\%29033\%5B01 76\%3AAOTGIA\%5D2.0.CO\%3B2>. Accessed: Sept. 08, 2014. doi: 10.1638/1042-7260(2002)033[0176:AOTGIA]2.0.CO;2. 